\title{
The key factors for selecting C2C Logistics Companies by using Fuzzy AHP in Thailand
}

\author{
Pongpanic Rapee ${ }^{1}$, Ke-Chung Peng ${ }^{2}$, Tzong-Ru Lee ${ }^{3}$ \\ ${ }^{1}$ IDepartment of Tropical Agriculture and International Cooperation, National Pingtung University of Science \\ and Technology, Taiwan, R.O.C. \\ ${ }^{2}$ Department of Agribusiness Management, National Pingtung University of Science and Technology, Taiwan, \\ R.O.C. \\ ${ }^{3}$ Departments of Marketing, National Chung Hsing University, Taichung, Taiwan, R.O.C.
}

\begin{abstract}
In Thailand, logistics companies (3PL provider) in customer to customer (C2C) online market have been becoming important part of Thai transportation. Logistics companies have been always used to convey product between customers. Thus, the key factors for selecting C2C logistics companies in Thailand have influence to customer. This paper conducts a review of the literature on logistics provider to generate sub-key factors along with key factors. A questionnaire survey and in-depth interview with key stakeholder are conducted by comparison the key factors. The main objective of this paper is to examine the relative importance weight and ranking of key factors that have implication to decision-making of logistics provider's customer. In this paper, proposed a multiple approach to access alternative and help the decision-maker to evaluate the key factor of C2C logistics companies by FAHP. The FAHP is used to simplify numerical calculation of multiple criteria weight by integrating fuzzy Logic and Analytic Hierarchy Process (AHP). In addition, based on the finding the priority of key factors and policy recommendation are provided to enable more effective criteria for selecting logistics companies in $C 2 C$ online market.
\end{abstract}

Keywords: key factors, C2C logistics company, 3PL provider, fuzzy AHP, Thailand

\section{Introduction}

In last decade, logistics in organization had played a significant role to the supply chain sector which was an element of business sector. Logistics was seemed to be an important factor in business around the world, because small and medium enterprises and industry sector have been used to increase their objectives as follows: reduce operation costs, save delivery times, improve customer service quality, company image and company reputation, (Yan, Chaudhry and Chaudhry 2003, Liu and Wang, 2009). Logistics can be regarded as an important mechanism for driving better business world in the previous times. But on the other hand, small and medium enterprises sector and industry didn't have apparently operation plan for running logistics sector to their work. Therefore, logistics outsourcing was used to solve problem inside organization by buildup more strong efficiency to their delivery operation. Moreover, logistics outsourcing always tried to develop themselves along with the variation of logistics. Thus, the evolution of logistics outsourcing was established from logistics in organization and lead to third-party logistics provider (3PL). 3PL is a logistics service provider that helps a firm convey product to customers. According to 3PL previous survey done by Boyson (Boyson et al., 1999) found that the most regular activities of logistics outsourcing were: warehousing, outbound transportation, customs brokerage, inbound transportation, inventory management, IT services, value added activities, and installation of products. Moreover, (Gol and satay, 2007) and (Boyson et al., 1999a) mentioned that 3PLs had evolution from offering a single function to integrating logistics provision. Therefore we can state that the evolution of logistics industry will have continually development follow the changes of global business environments.

Currently, Thai Retails Association reported that in Thailand had convenience store was the largest number of retail industry, there were convenience stores by 12,246 unit. Second largest number of unit was supermarket which had units about 531units, third largest number of unit was hypermarkets had units by 92 units and fourth largest number of unit was warehouse-clubs had only 41 units as of the end of 2013. Meanwhile the result of National Statistics Office Thailand, 2013 (NSO) found that the retail trend had rapidly change in Thailand as moving forward of foreign department stores such as Big C, TESCO Lotus and Carrefour, have directly affected on traditional trade or grocery in Thailand. According to AC Nielsen reported in 2013, there were four types of modern retailer in Thailand that including; convenience stores, supermarket, hypermarket and warehouse-clubs, respectively.

In addition, when we consider deeply to the Thai retail market, we found that there were many retailers have been selling products to online market and also found that the number of retailers in term of $\mathrm{C} 2 \mathrm{C}$ had been growing up every year. The $\mathrm{C} 2 \mathrm{C}$ online market of Thailand is considered be a new channel of products distribution. Moreover, the growth of online market in Thailand will depend on the number of internet users 
and purchasing demand. The retail environment has been one most important element of business environments which had influence to evolution of logistics industry. Based on the transport sector, 3PL will be evolved their service form step-by-step. Hence the major players in $\mathrm{C} 2 \mathrm{C}$ online market are 3PL service provider. As the previous paragraphs, it can conclude that the evolution of logistics industry will have consistency with change of retail environment and those consumers in $\mathrm{C} 2 \mathrm{C}$ online market have such relationship with the important factor.

Therefore, the motivation of this study is to deeply understanding that "what is best criteria for selecting C2C logistics companies", "which decision tool is helped buyer and seller identify important factors", "how many number of key factor is suitable for selecting C2C logistics companies". Therefore, it is necessary to study and demonstrate actuality in this research.

\subsection{Classification of business in e-commerce market}

\section{Literature review}

According to "e-commerce" is the new distribution channel which emerges in recent years, Ecommerce is becoming a new powerful distribution channel for conducting business in online market. Moreover, e-commerce will help businesses have good relationships with customers during their operations which includes business-supplier, business-client, business-to-end consumer and customer to customer (Gunasekaran et al., 2002). Thus, we can classify a business on internet as follows.

B2B (Business-to-Business) is a contemporary marketplace for long term sale practice in B2B market. The task of B2B marketplace is to support coordination between businesses. Thus, coordination of business in B2B's context will consist of both transaction and interaction. Transaction is the exchange process of goods and services, informational, physical and financial activities. While, interaction will comprises only the planning procedure for transformation of goods. But in fact, the traditional B2B marketplaces have considered only the transactions. Therefore, transactions of B2B will focus only on business and suppliers. Meanwhile when infrastructure of internet system has been built in each country, the growth of electronic communications will grow which is consistency with good infrastructure. Thus, B2B e-commerce, become important players in global market and it also simply replace on traditional B2B marketplaces, nowadays.

B2C (business-to-consumer) is one of the retailer in business section of the online market, is often contrasted with B2B. The task of B2C marketplace is supported buyers and help buyers look for the best products on product's database which have offered by sellers. Thus, an increase in the use of business-toconsumer (B2C) may have associations regarding mobility of person, because it occurs convenience way to consumer around the world (Weltevreden et al., 2009). Meanwhile, B2C can help internet users (consumer) directly order to producer or manufacture. Besides, B2C can also help customer discuss about element of product via internet browser. Thus, $\mathrm{B} 2 \mathrm{C}$ e-commerce markets are becoming convenience tools which have rapid respond to customer's need (Gefen et al., 2003). Furthermore, B2C e-commerce markets have become interested in the implications one of distribution center, because it is significant with customer and freight transport (Golob and Regan 2001, Mokhtarian 2002). However, other research claims that online shoping will have a limited or even a neutral impact on the number of shopper and distance for shopping (Golob and Regan, 2001a; Keskinen et al., 2002a; Mokhtarian, 2004a). Thus, as the previous paragraph and a vast number of empirical studies, it can conclude that $\mathrm{B} 2 \mathrm{C}$ is a substitute for entrepreneur who want to sell product to customer.

Nowadays $\mathrm{C} 2 \mathrm{C}$ is the abbreviation of business-to-consumer which has transaction in electronic commerce market. $\mathrm{C} 2 \mathrm{C}$ online market is an electronic internet-facilitated that involves transactions between customers to customers. These $\mathrm{C} 2 \mathrm{C}$ e-commerce market, including: the use of online auctions, web forums, chat rooms, online shopping, or e-shopping, and bid to purchase the goods (Burt and Sparks, 2003; Wrigley et al., 2002; Weltevreden, 2007 and Kiku, 2008). Besides, C2C also is a modern platform of barter, flea markets, yard sales and swap meets, but it has some disadvantages such as limited payment options and lack of quality control. A few years ago, when there is consideration in term of the frequency of internet users, it found that the frequency of internet user who want to buy and sell products to other consumers were continually increase (Weltevreden, 2007a).

Thus, it can state that $\mathrm{C} 2 \mathrm{C}$ online market becomes popular trading tool nowadays. Moreover, there are many internet browsers and traditionally-based of electronic commerce use for serving to business and consumer. Thus, as previous paragraphs can state that there are three marketplaces are easier way to access commercial online market more than another way.

\subsection{Empirical factor for logistics provider selection}

There are many real cases of important factors are often occurred in the $\mathrm{C} 2 \mathrm{C}$ e-commerce market and other related market. According to the frequency of reference in text book and the literature, the key factors and sub-key factor as the frequency of reference in book and the literature which have relating in term of the multicriteria decision marking are selected. Thus, the suitable key factors and sub-factor for selecting C2C logistics companies will be presented as below. 
As the interesting about price of service in $\mathrm{C} 2 \mathrm{C}$ logistics companies, price is amount of money that customer have to pay for buying some service in delivery. Especially transportation price has association between price and delivery service (Stank et al., 2003). Price of transportation will depend on the quantity and category of product and the behavior of customer (Liang et al., 2006). In addition, the customer will concentrates on moving goods from point to point by reason of packaging price, goods safety and insurance price. Packaging can help entrepreneurs in $\mathrm{C} 2 \mathrm{C}$ online market keep the quality of goods and help them to protect impact force from the outside (Young. 2000). Packaging price has more important to control the system of logistics (Dubiel. 1996). While, insurance price will help entrepreneurs keep money from accident during conveying. Insurance price of transport goods will differ from insurance price of passenger. An average price of insurance is calculated from quantity and quality of product. The overall average price (rate) is required for all risk classes (Hickson. 2006). Hence, insurance price will be able to determine the price from classification by risk level of people.

According to important factor, history of company has been used to consider C2C logistics companies from customers when they want to buy some logistics service. With customer's consideration can explain the attitude from company's history in the next circumstance. Fairness is one of key successful in logistics service provider, the company should be perceived as being fair on their service (Spencer et al., 1994). While trust will occur after fairness when customer use service. Trust was indeed an imperative for successful in service (Tate. 1996). In addition, emphasizing of financial soundness is an essential for logistics company. Customer of logistics service provider will consider financial stability and qualification of company, before they buy service from logistics company. As the customer' awareness, financial stability may be perceived as a very important attribute in the assessment process (Menon et al., 1998). Moreover, the experience of company has been used to compare the capability between logistics companies. The experience will occur with work process in logistics service and will be effected to awareness of customer (Barua and Lee. 1997). Normally, experience of company will appear together with quality of service after customers have already received service from company. Thus, as previous paragraph can mention that the customer can assess the quality of company's service from history (Chang and Yeh. 2005).

Logistics information systems and technology are being recognized as an essential driver of business success in global online marketplace. The last decade had seen an unprecedented rate of development of computer hardware and software which had been often use around the world. Especially in south east Europe (Ketikidis et al., 2008). During this period, the concept of the Logistics Information System (LIS) has evolved from original information system in third party logistics. Logistics information systems and technology will requires a coordinated efforts for linking with planning, organizing, controlling, directing the introduction and IT using within a firm. Information system and technology is an important tool in 3PL services providers. It enhances the ability to deliver and provides significant improvement in financial stability, operational performance, cost of service in long run, and uncertainties in logistics operation (Jharkharia et. at., 2007). Moreover, 3PL services provider should be trustworthy and should be work with information sharing. As the empirical study of author, the information sharing can exchange important data at each stage of logistics activity. It helps to connect the gap of delivery and also creates new activity in technology system, organization and operation practices. Thus, the high-technology plant must has modification and updating are often, because it helps organization reduce their risk regarding information technology management (Rahman and Qureshi. 2007).

Customer relationship management strategy can also create valuable marketing opportunities, increase customer value and enhance customer satisfaction in logistics business. It can indicate that communicationdistribution infrastructure, business dynamics, customer relations and innovation quality into organization's proration can help organization increase the royalty (Ozgener and Iraz. 2006). While, the choice of the right partner can yield important competitive benefits. The selection of a suitable partner for strategic alliance is an important factor which direct affect to performance in logistics value chain. The careful assessment in a logistics value chain has an important strategic outcome and lead to creating competitive advantage (Buyukozkan et al., 2008).

Many services and industrial product markets are same characterized by increasing quality of generic production, pricing and promotion. The differentiation of service or industrial product are possible by reducing lead times between production and consumption. An improvement of product and service in logistics providers are better for customer who focus on lead time reduction. Most of logistics providers try to focus on lead time reduction, because it will be help improving their transfer during service (Treville et al., 2004). Moreover, ontime delivery have influence to customer decision-marking to buy product and service. On-time delivery is critical criteria when buyers choose to manage their time. It also important for determine cooperative cost which occurs in logistics practice (Lin. 2008). Many customers can get value and profitable from creating competitive advantages of product and service. One of all competitive advantages is prompt response to claim. It helps customer understand the logistics providers 'operation and indicates service attributes of logistics activities (Lu. 
2003). While, delivery accuracy are used to determine delivery time distribution in activity of logistics service. Delivery accuracy is important and influence to create satisfaction of their customer.

Moreover, as diversity in the logistics environment, flexibility is important service that concern in operation management. It may enable to give a special service to their customers. Logistics service providers should be responded by adding flexibility to their operation strategies (Duclos et al., 2003). Thus, as previous literature can create the structure of Analytic Hierarchy Process in this research are show in Figure 1.

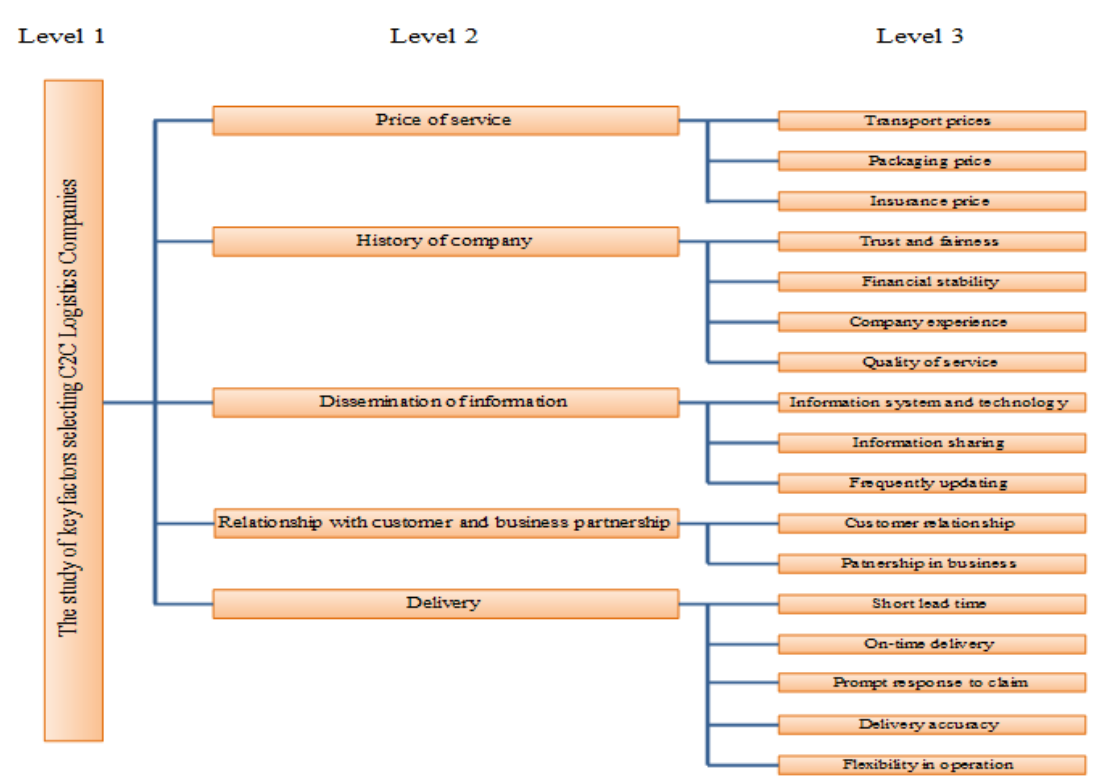

Fig 1. The structure of Analytic Hierarchy Process

\subsection{Analytic Hierarchy Process}

\section{Materials and Methods}

Analysis Hierarchy Process (AHP) is a decision-making method has been used in the analysis system. This method has been developed in 1971 by Saaty for response to allocate and planning of scare resource in the military (Saaty 1980; Wong and Chou 2006; Lee et al., 2008) is a comprehensive evaluation method. This method is flexible and is powerful for solving complex multi-criteria decision problems. AHP is a prioritized ranking or weighting of each alternative decision process which is easy to use, because of structural imitation of human brain. These decision-making processes have good performance and widely used in complex multicriteria decision problems. Thus, in various research areas are assembled by healthcare, politics, economics, social, supplier selection, reverse logistics selection, logistics service provider selection, engineering process selection, software selection, management science and so on (Jian 2005; Wong and Chouha 2006; Lee et al., 2008; and Kannan 2009). Moreover, AHP technique is adopted into software selection of this group decision environment by ranking the software. The health system patient management decisions are extremely complex (Dolan 2008). This system consists of the working knowledge base, the clinical circumstance, the patient's preferences \& values and other stakeholders' preference \& value which all elements influence to patient care decisions.

Although, the AHP method is wildly used, it still have some disadvantage such as this method is mainly used in nearly crisp decision application, it is use of an unbalanced scale of estimation and ranking of AHP. Thus, this research integrates the concept of fuzzy set theory with AHP approach.

\section{Step 1: Decomposition}

The problems are clearly defined. The overall goal is identified and to determine the evaluation criteria. Then, the decision hierarchy is structured into the hierarchy which the similar feature are grouped at the same level.

\section{Step 2: Pair-wise comparison}

All indicators in the same level are compared in pair-wise comparison matrices. In order to determine the relative important of indicator, Satty's an inter-value 1-9 scale are consider.

\section{Step 3: Estimate the relative weights}

The eigenvector method is applied to generate the relative weight in each pare-wise comparison matrix. 
Step 4: Check the consistency

The consistency is checked to ensure that the judgments of decision makers are consistent.

Consistency Index (CI)

$$
\text { C.I. }=\frac{(\lambda-\mathrm{n})}{(\mathrm{n}-1)}
$$

Where $\lambda$ = the biggest eigenvalue of matrix

Consistency Ratio (CR)

$$
\mathrm{CR}=\frac{\mathrm{CI}}{\mathrm{RI}}
$$

Where RI represent the average consistency index over abundant random entries of same order reciprocal matrices. (If $\mathrm{RI} \leq 0.1$, the estimate is accepted)

\subsection{Fuzzy Analytic Hierarchy Process}

According to previous fuzzy set theory (Zadeh. 1965), a fuzzy set has been one class of objects that is defined into membership function. The membership function $\mu \mathrm{A}$ (x) can be operated cover by the interval of real number. Hence a fuzzy set can be identified the symbol by represents a tilde “ $\sim$ ", then it will be indicated by placing above a symbol, is show in fig. 2. Meanwhile the triangular fuzzy numbers (TFNs) in this study are used to represent pairwise comparison method. This the triangular fuzzy numbers (TFNs) are also identified the symbol as (l, m, u). Especially the parameters "l", "m" and "u" have possible value are smallest. But on the other hand, when the value of (TFN) are the largest possible value, then these symbols $(1, m, u)$ will become a non-fuzzy number.

$$
\mu_{\bar{M}}=\left\{\begin{array}{l}
\mathrm{O}, x<l, \\
(x-1) /(m-l), l \leq x \leq m, \\
(u-x) /(u-m), m \leq x \leq u, \\
0, x>u .
\end{array}\right\}
$$

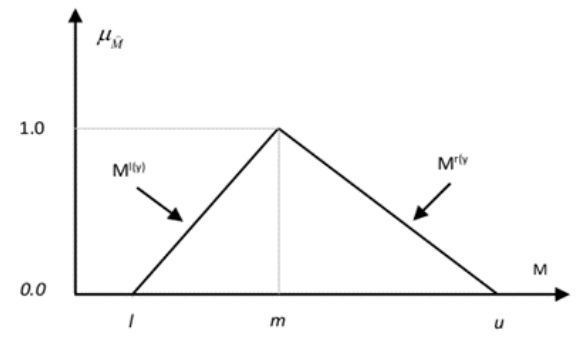

Fig 2. A triangular fuzzy number, $\widehat{M}$

In term of membership in real fuzzy number and triangular fuzzy numbers, they can identify origin of real number function in this study by representation as below;

$$
\widehat{\mathbf{M}}=\widehat{\mathbf{M}}^{l(y)}, \mathrm{M}^{r(y)}=(l+(M-l) y, u+(m-u) y), y \in[0,1]
$$

Given $1(\mathrm{y})$ and $\mathrm{r}(\mathrm{y})$ place the left side and right side of a fuzzy number.

\subsection{Linguistic variables}

The Triangular fuzzy numbers have been using to represent the subjective of human's judgments in term of pair-wire comparison. They have complex quantification when want to express reasonable decisionmaking. As Zadeh (Zadeh 1965) had proposed linguistic variables, this concept is modified to illuminate the complexity of human's judgments and formulated the human reasoning. The linguistic variables are show in Table 1.

Table. 1 Linguistic variables

\begin{tabular}{|l|c|}
\hline Linguistic variables & Triangular fuzzy numbers \\
\hline Equally important & $(1,1,1)$ \\
\hline Weakly more important & $(2 / 3,1,3 / 2)$ \\
\hline Strongly more important & $(3 / 2,2,5 / 2)$ \\
\hline Very strongly more important & $(5 / 2,3,7 / 2)$ \\
\hline Absolutely more important & $(7 / 2,4,9 / 2)$ \\
\hline
\end{tabular}

\subsection{Extent analysis method on fuzzy AHP}

The steps of Chang's extent analysis can be given as in the following (Kahraman et al., 2004): 
3.4.1. The value of fuzzy synthetic extent with respect to $i$ th object is defined as

$S_{i}=\sum_{j=1}^{m} M_{g_{i}}^{j} \otimes\left[\sum_{i=1}^{n} \sum_{j=1}^{m} M_{g_{i}}^{j}\right]^{-1}$

To obtain $\sum_{j=1}^{m} \mathrm{M}_{g_{i}}^{j}$, perform the fuzzy addition operation of $m$ extent analysis values for a particular matrix such that

$$
\sum_{j=1}^{m} \mathrm{M}_{g_{i}}^{j}=\left(\sum_{j=1}^{m} l_{j} \sum_{j=1}^{m} m_{j} \sum_{j=1}^{m} u_{j}\right)
$$

and to obtain $\left[\sum_{i=1}^{n} \sum_{j=1}^{m} \sum_{g_{i}}^{j}\right]^{-1}$, perform the fuzzy addition operation of $\mathrm{M}_{g_{i}}^{j}(j=1,2, \ldots, m)$

values such that

$$
\sum_{i=1}^{n} \sum_{j=1}^{m} M_{g_{i}}^{j}=\left(\sum_{i=1}^{n} l_{i} \sum_{i=1}^{n} m_{i} \sum_{i=1}^{n} u_{i}\right)
$$

and then compute the inverse of the vector in Eq.(3) such that

$$
\left[\sum_{i=1}^{n} \sum_{j=1}^{m} M_{g_{i}}^{j}\right]^{-1}=\left(\frac{1}{\sum_{i=1}^{n} u_{i}}, \frac{1}{\sum_{i=1}^{n} m_{i}}, \frac{1}{\sum_{i=1}^{n} l_{i}}\right)
$$

(3.4.2) The degree of possibility of $M_{2}=\left(l_{2}, m_{2}, u_{2}\right) \geq M_{1}=\left(l_{1}, m_{1} u_{1}\right)$ is defined as

$$
V\left(M_{2} \geq M_{1}\right)=\sup \left\lfloor\min \left(\mu_{m_{1}}(x), \mu_{m_{2}}(y)\right)\right\rfloor
$$

and can be equivalently expressed as follows:

$$
\begin{aligned}
& V\left(M_{2} \geq M_{1}\right)=\operatorname{hgt}\left(M_{1} \cap M_{2}\right)=\mu_{m_{2}}(d) \\
& =\quad\left\{\begin{array}{ll}
1, & \text { if } m_{2} \geq m_{1_{2}} \\
0, & \text { if } l_{1} \geq u_{2}, \\
\frac{l_{1}-u_{2}}{\left(m_{2}-u_{2}\right)-\left(m_{1}-l_{1}\right)}, & \text { otherwise, }
\end{array}\right\}
\end{aligned}
$$

Where $d$ is the ordinate of the highest intersection point $D$ between $\mu_{M_{1}}$ and $\mu_{M_{2}}$ In Fig. 3, the intersection between $M 1$ and $M 2$ can be seen.

To compare $M_{1}$ and $M_{2}$, we need both the values of $V\left(M_{1} \geq M_{2}\right)$ and $V\left(M_{2} \geq M_{1}\right)$

(3.4.3) The degree of possibility for a convex fuzzy number to be greater than $k$ convex fuzzy numbers $M_{i}(\mathrm{i}=1,2, \ldots, \mathrm{k})$ can be de-fined by

$V\left(M \geq M_{1}, M_{2}, \ldots, M_{k}\right)=V\left(M \geq M_{1}\right)$ and $\left(M \geq M_{2}\right)$

and...and $\left(M \geq M_{k}=\min v\left(M \geq M_{i}\right), i=1,2,3, \ldots, k\right.$. $)$

Assume that

$d^{\prime}\left(A_{i}\right)=\min V\left(S_{i} \geq S_{k}\right)$

Fork $=1,2, \ldots, \mathrm{n} ; \mathrm{k}-\mathrm{i}$. Then the weight vector is given by

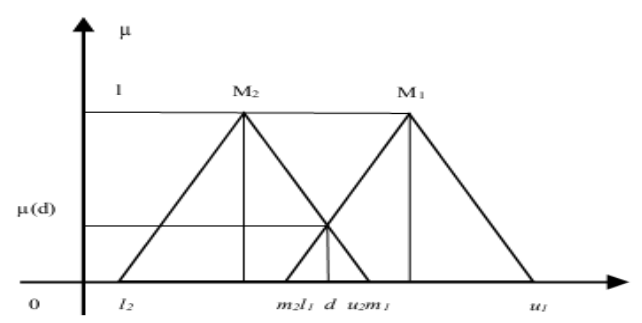

Fig. 3. The intersection betweenM1andM2.

$W^{\prime}=\left(d^{\prime}\left(A_{1}\right), d^{\prime}\left(A_{2}\right), \ldots, d^{\prime}\left(A_{m}\right)\right)^{T}$,

Where $\mathrm{Ai}(\mathrm{i}=1,2, \ldots, \mathrm{n})$ are $\mathrm{n}$ elements. 
(3.4.4) Normalization

As the real numbers, they have many non-normalization are appeared in Triangular Fuzzy Number. In this study is obtained normalization approach to solve problem by simple geometric mean as equation below;

Normalization

$$
W=\frac{W_{i}}{\sum_{i=1}^{i=n} W_{i}}
$$

Via normalization, the normalized weight vectors are $W=\left(d\left(A_{1}\right), d\left(A_{2}\right), \ldots, d\left(A_{n}\right)\right)^{T}$,

Where $W$ is a non-fuzzy number. This gives the priority weights of one alternative over another.

\subsection{Calculation of global weights}

As the empirical study, there were three levels in establishment of decision hierarchy structure as stating of Gol (Gol 2007). It can be calculated the global weight of each element by using the local weight (Wi) of factor in level 2 multiply the sub-factor in level 3. As demonstration of sheu (Sheu 2004), the calculation become a global weight of each element is proposed as formula below

$$
\mathrm{S}=\alpha \times \beta
$$

Given $\mathrm{S}$ is the global weight, $\alpha$ is the local weight of the factor in level $2, \beta$ is the local weight of the sub-key factor level 3

When we obtain the priorities of each alternative, the decision maker can select the great alternative from multi-alternatives in level 3 which is important regarding to key factors.

\section{Application of Constrain Fuzzy AHP to the key factors selecting}

According to Eq. (3)-(12) overall criteria weight for high ranking are calculated.

By using formula (2) and taking the average value. Then, applying formula (7), into this research $\mathrm{S}_{1}=(6.17,8.00,10.00) \times(1 / 38.97,1 / 32.33,1 / 26.60)=(0.16,0.25,0.38)$,

$\mathrm{S}_{2}=(4.89,6.25,7.79) \times(1 / 38.97,1 / 32.33,1 / 26.60)=(0.13,0.19,0.29)$,

$\mathrm{S}_{3}=(4.19,4.83,5.57) \times(1 / 38.97,1 / 32.33,1 / 26.60)=(0.11,0.15,0.21)$,

$\mathrm{S}_{4}=(3.74,4.50,5.67) \times(1 / 38.97,1 / 32.33,1 / 26.60)=(0.10,0.14,0.21)$,

$\mathrm{S}_{5}=(7.62,8.75,9.95) \times(1 / 38.97,1 / 32.33,1 / 26.60)=(0.20,0.27,0.37)$

Using formulas (9) and (10),

$\mathrm{V}\left(\mathrm{S}_{1} \geq \mathrm{S}_{2}\right)=1, \mathrm{~V}\left(\mathrm{~S}_{1} \geq \mathrm{S}_{3}\right)=1, \mathrm{~V}\left(\mathrm{~S}_{1} \geq \mathrm{S}_{4}\right)=1$

$\mathrm{V}\left(\mathrm{S}_{1} \geq \mathrm{S}_{5}\right)=\frac{0.14-0.39}{(0.25-0.39)-(0.17-0.14)}=0.890$

$\mathrm{V}\left(\mathrm{S}_{2} \geq \mathrm{S}_{1}\right)=\frac{0.12-0.39}{(0.25-0.39)-(0.17-0.12)}=0.713$

$\mathrm{V}\left(\mathrm{S}_{2} \geq \mathrm{S}_{3}\right)=1, \mathrm{~V}\left(\mathrm{~S}_{2} \geq \mathrm{S}_{4}\right)=1, \mathrm{~V}\left(\mathrm{~S}_{2} \geq \mathrm{S}_{5}\right)=0.557$,

$\mathrm{V}\left(\mathrm{S}_{3} \geq \mathrm{S}_{1}\right)=0.343, \mathrm{~V}\left(\mathrm{~S}_{3} \geq \mathrm{S}_{2}\right)=0.657, \mathrm{~V}\left(\mathrm{~S}_{3} \geq \mathrm{S}_{4}\right)=1, \mathrm{~V}\left(\mathrm{~S}_{3} \geq \mathrm{S}_{5}\right)=1$

$\mathrm{V}\left(\mathrm{S}_{4} \geq \mathrm{S}_{1}\right)=0.336, \mathrm{~V}\left(\mathrm{~S}_{4} \geq \mathrm{S}_{2}\right)=0.618, \mathrm{~V}\left(\mathrm{~S}_{4} \geq \mathrm{S}_{3}\right)=0.911, \mathrm{~V}\left(\mathrm{~S}_{4} \geq \mathrm{S}_{5}\right)=0.117$

$\mathrm{V}\left(\mathrm{S}_{5} \geq \mathrm{S}_{1}\right)=1 \mathrm{~V}\left(\mathrm{~S}_{5} \geq \mathrm{S}_{2}\right)=1 \mathrm{~V}\left(\mathrm{~S}_{5} \geq \mathrm{S}_{3}\right)=1 \mathrm{~V}\left(\mathrm{~S}_{5} \geq \mathrm{S}_{4}\right)=1$

Final, by using formula (12), we obtain

$\mathrm{d}^{\prime}\left(\mathrm{C}_{1}\right)=\mathrm{V}\left(\mathrm{S}_{1} \geq \mathrm{S}_{2}, \mathrm{~S}_{3}, \mathrm{~S}_{4}, \mathrm{~S}_{5}\right)=\min (1.00,1.00,1.00,0.886)=0.886$

$\mathrm{d}^{\prime}\left(\mathrm{C}_{2}\right)=\mathrm{V}\left(\mathrm{S}_{2} \geq \mathrm{S}_{1}, \mathrm{~S}_{3}, \mathrm{~S}_{4}, \mathrm{~S}_{5}\right)=\min (0.713,1.00,1.00,0.557)=0.557$

$\mathrm{d}^{\prime}\left(\mathrm{C}_{3}\right)=\mathrm{V}\left(\mathrm{S}_{3} \geq \mathrm{S}_{1}, \mathrm{~S}_{2}, \mathrm{~S}_{4}, \mathrm{~S}_{5}\right)=\min (0.343,0.657,1.00,0.102)=0.038$

$\mathrm{d}^{\prime}\left(\mathrm{C}_{4}\right)=\mathrm{V}\left(\mathrm{S}_{4} \geq \mathrm{S}_{1}, \mathrm{~S}_{2}, \mathrm{~S}_{3}, \mathrm{~S}_{5}\right)=\min (0.336,0.618,0.911,0.117)=0.117$

$\mathrm{d}^{\prime}\left(\mathrm{C}_{5}\right)=\mathrm{V}\left(\mathrm{S}_{5} \geq \mathrm{S}_{1}, \mathrm{~S}_{2}, \mathrm{~S}_{3}, \mathrm{~S}_{4}\right)=\min (1.00,1.00,1.00,1.00)=1.00$

Therefore

$\mathrm{W}=(0.886,0.557,0.038,0.117,1.00)^{\mathrm{T}}$

via normalization, and we have obtained the weight vectors with respect to the decision criteria CI, C 2, C 3 and C4:

$\mathrm{W}=(0.333,0.209,0.038,0.044,0.376)^{\mathrm{T}}$

At the second level of the decision procedure, the committee compares candidates A 1, A 2 and A 3 under each of the criteria separately. This results in the matrices, 1,2,3 and 4, which are shown in Tables 3 to Table 7 . 
Table 2. The aggregate ordinal number in level 2

\begin{tabular}{|c|c|c|c|c|c|c|}
\hline \multirow{2}{*}{$\begin{array}{l}\text { Key } \\
\text { Factors }\end{array}$} & $\begin{array}{c}\mathrm{C} 1: \\
\text { Price of } \\
\text { Service, }\end{array}$ & $\begin{array}{c}\mathrm{C} 2: \\
\text { History of } \\
\text { Company }\end{array}$ & $\begin{array}{c}\text { C3: Dissemination } \\
\text { of Information }\end{array}$ & $\begin{array}{c}\text { C4: Relationship } \\
\text { with Customer }\end{array}$ & $\begin{array}{c}\text { C5: } \\
\text { Delivery }\end{array}$ \\
\cline { 2 - 7 } & $(1, \mathrm{~m}, \mathrm{u})$ & $(1, \mathrm{~m}, \mathrm{u})$ & $(1, \mathrm{~m}, \mathrm{u})$ & $(1, \mathrm{~m}, \mathrm{u})$ & $(1, \mathrm{~m}, \mathrm{u})$ \\
\hline $\mathrm{C}_{1}$ & $1,1,1$ & $2 / 3,1,3 / 2$ & $3 / 2,2,5 / 2$ & $3 / 2,2,5 / 2$ & $3 / 2,2,5 / 2$ & 0.333 \\
\hline $\mathrm{C}_{2}$ & $2 / 9,1 / 4,2 / 7$ & $1,1,1$ & $3 / 2,2,5 / 2$ & $3 / 2,2,5 / 2$ & 0.209 \\
\hline $\mathrm{C}_{3}$ & $2 / 5,1 / 2,2 / 3$ & $2 / 7,1 / 3,2 / 5$ & $1,1,1$ & $3 / 2,2,5 / 2$ & 0.038 \\
\hline $\mathrm{C}_{4}$ & $2 / 3,1,3 / 2$ & $2 / 5,1 / 2,2 / 3$ & $2 / 7,1 / 3,2 / 5$ & $1,1,1$ & $1,1,1$ \\
\hline $\mathrm{C}_{5}$ & $2 / 5,1 / 2,2 / 3$ & $2 / 9,1 / 4,2 / 7$ & $3 / 2,2,5 / 2$ & $7 / 2,4,9 / 2$ & 0.044 \\
\hline
\end{tabular}

Table 3. The aggregate ordinal number in level 3

\begin{tabular}{|c|c|c|c|c|}
\hline \multirow{2}{*}{$\begin{array}{l}\text { Sub-key } \\
\text { Factors }\end{array}$} & $\begin{array}{c}\mathrm{C}_{11}: \\
\text { Transport price }\end{array}$ & $\begin{array}{c}\mathrm{C}_{12}: \\
\text { Packaging price }\end{array}$ & $\begin{array}{c}\mathrm{C}_{13}: \\
\text { Insurance price }\end{array}$ & \multirow{2}{*}{ Weight } \\
\cline { 2 - 4 } & $(1, \mathrm{~m}, \mathrm{u})$ & $(1, \mathrm{~m}, \mathrm{u})$ & $(1, \mathrm{~m}, \mathrm{u})$ & 0.454 \\
\hline $\mathrm{C}_{11}$ & $1,1,1$ & $2 / 3,1,3 / 2$ & $3 / 2,2,5 / 2$ & 0.379 \\
\hline $\mathrm{C}_{12}$ & $2 / 5,1 / 2,2 / 3$ & $1,1,1$ & $3 / 2,2,5 / 2$ & 0.167 \\
\hline $\mathrm{C}_{13}$ & $2 / 3,1,3 / 2$ & $2 / 7,1 / 3,2 / 5$ & $1,1,1$ & 0.167 \\
\hline
\end{tabular}

Table 4. The aggregate ordinal number in level 3

\begin{tabular}{|c|c|c|c|c|c|}
\hline \multirow{2}{*}{$\begin{array}{l}\text { Sub-key } \\
\text { Factors }\end{array}$} & $\begin{array}{c}\mathrm{C}_{21}: \\
\text { Trust and fairness }\end{array}$ & $\begin{array}{c}\mathrm{C}_{22}: \\
\text { Financial stability }\end{array}$ & $\begin{array}{c}\mathrm{C}_{23}: \text { Company } \\
\text { experience }\end{array}$ & $\begin{array}{c}\mathrm{C}_{24}: \\
\text { Quality of service }\end{array}$ & Weight \\
\cline { 2 - 5 } & $(1, \mathrm{~m}, \mathrm{u})$ & $(1, \mathrm{~m}, \mathrm{u})$ & $(1, \mathrm{~m}, \mathrm{u})$ & $(1, \mathrm{~m}, \mathrm{u})$ & 0.151 \\
\hline $\mathrm{C}_{21}$ & $1,1,1$ & $3 / 2,2,5 / 2$ & $2 / 3,1,3 / 2$ & $2 / 7,1 / 3,2 / 5$ & 0.036 \\
\hline $\mathrm{C}_{22}$ & $2 / 3,1,3 / 2$ & $1,1,1$ & $2 / 5,1 / 2,2 / 3$ & $2 / 3,1,3 / 2$ & 0.189 \\
\hline $\mathrm{C}_{23}$ & $2 / 7,1 / 3,2 / 5$ & $5 / 2,3,7 / 2$ & $1,1,1$ & $2 / 5,1 / 2,2 / 3$ & 0.623 \\
\hline $\mathrm{C}_{24}$ & $2 / 3,1,3 / 2$ & $5 / 2,3,7 / 2$ & $5 / 2,3,7 / 2$ & $1,1,1$ & \\
\hline
\end{tabular}

Table 5. The aggregate ordinal number in level 3

\begin{tabular}{|c|c|c|c|c|}
\hline \multirow{2}{*}{$\begin{array}{l}\text { Sub-key } \\
\text { Factors }\end{array}$} & $\begin{array}{c}\mathrm{C}_{31}: \text { Information } \\
\text { system and } \\
\text { technology }\end{array}$ & $\begin{array}{c}\mathrm{C}_{32} \text { : Information } \\
\text { sharing }\end{array}$ & $\begin{array}{c}\mathrm{C}_{33} \text { : Frequently } \\
\text { updating }\end{array}$ & \multirow{2}{*}{ Weight } \\
\cline { 2 - 4 } & $(\mathrm{l}, \mathrm{m}, \mathrm{u})$ & $(1, \mathrm{~m}, \mathrm{u})$ & $(1, \mathrm{~m}, \mathrm{u})$ & 0.454 \\
\hline $\mathrm{C}_{31}$ & $1,1,1$ & $3 / 2,2,5 / 2$ & $2 / 3,1,3 / 2$ & 0.167 \\
\hline $\mathrm{C}_{32}$ & $2 / 3,1,3 / 2$ & $1,1,1$ & $2 / 7,1 / 3,2 / 5$ & 0.379 \\
\hline $\mathrm{C}_{33}$ & $2 / 5,1 / 2,2 / 3$ & $3 / 2,2,5 / 2$ & $1,1,1$ & 0.379 \\
\hline
\end{tabular}

Table 6. The aggregate ordinal number in level 3

\begin{tabular}{|c|c|c|c|}
\hline \multirow{2}{*}{ Sub-key Factors } & $\mathrm{C}_{41}$ : Customer relationship & $\begin{array}{c}\mathrm{C}_{42} \text { : Partnership in } \\
\text { business }\end{array}$ & \multirow{2}{*}{ Weight } \\
\cline { 2 - 3 } & $(1, \mathrm{~m}, \mathrm{u})$ & $(1, \mathrm{~m}, \mathrm{u})$ & \\
\hline $\mathrm{C}_{41}$ & $1,1,1$ & $1 / 2,1,3 / 2$ & 0.625 \\
\hline $\mathrm{C}_{42}$ & $2 / 5,1 / 2,2 / 3$ & $1,1,1$ & 0.375 \\
\hline
\end{tabular}

Table 7. The aggregate ordinal number in level 3

\begin{tabular}{|c|c|c|c|c|c|c|}
\hline \multirow{2}{*}{$\begin{array}{l}\text { Key } \\
\text { Factors }\end{array}$} & $\begin{array}{c}\mathrm{C}_{51}: \\
\text { Short lead time }\end{array}$ & $\begin{array}{c}\mathrm{C}_{52}: \\
\text { On-time } \\
\text { delivery }\end{array}$ & $\begin{array}{c}\mathrm{C}_{53}: \\
\text { Prompt } \\
\text { response to } \\
\text { claim }\end{array}$ & $\begin{array}{c}\mathrm{C}_{54}: \\
\text { Delivery } \\
\text { accuracy }\end{array}$ & $\begin{array}{c}\mathrm{C}_{55}: \text { Flexibility } \\
\text { in operation }\end{array}$ & Weight \\
\cline { 2 - 7 } & $(1, \mathrm{~m}, \mathrm{u})$ & $(1, \mathrm{~m}, \mathrm{u})$ & $(1, \mathrm{~m}, \mathrm{u})$ & $(1, \mathrm{~m}, \mathrm{u})$ & $(1, \mathrm{~m}, \mathrm{u})$ & 0.266 \\
\hline $\mathrm{C}_{51}$ & $1,1,1$ & $2 / 9,1 / 4,2 / 7$ & $2 / 3,1,3 / 2$ & $2 / 3,1,3 / 2$ & $5 / 2,3,7 / 2$ & 0.450 \\
\hline $\mathrm{C}_{52}$ & $2 / 3,1,3 / 2$ & $1,1,1$ & $3 / 2,2,5 / 2$ & $2 / 3,1,3 / 2$ & $2 / 3,1,3 / 2$ & 0.044 \\
\hline $\mathrm{C}_{53}$ & $2 / 5,1 / 2,2 / 3$ & $2 / 3,1,3 / 2$ & $1,1,1$ & $2 / 7,1 / 3,2 / 5$ & $3 / 2,2,5 / 2$ & 0.105 \\
\hline $\mathrm{C}_{54}$ & $2 / 9,1 / 4,2 / 7$ & $2 / 7,1 / 3,2 / 5$ & $2 / 3,1,3 / 2$ & $1,1,1$ & $1,1,1$ & 0.135 \\
\hline $\mathrm{C}_{55}$ & $2 / 3,1,3 / 2$ & $2 / 3,1,3 / 2$ & $2 / 5,1 / 2,2 / 3$ & $2 / 3,1,3 / 2$ & & \\
\hline
\end{tabular}

As the result Table 2-7, the value is an important validating parameter in FAHP. It is used as a reference index to distinguish those information by calculating the consistency ratio CR. Moreover, Table 8 show the value of the random consistency index (RI) for matrix of level 2 and level 3 that are obtained by approximating random indices using a sample size of 400 . 
Table 8.Average random index (RI) based on matrix size

\begin{tabular}{|c|c|c|c|c|c|c|c|c|c|c|}
\hline $\mathrm{N}$ & 1 & 2 & 3 & 4 & 5 & 6 & 7 & 8 & 9 & 10 \\
\hline $\mathrm{CRI}$ & 0 & 0 & 0.52 & 0.89 & 1.11 & 1.25 & 1.35 & 1.40 & 1.45 & 1.49 \\
\hline
\end{tabular}

After calculation, the consistency ratio of each comparison matrix in each level were found to be under 0.10 . Thus the consistency of pair-wise judgment in all matrix is acceptable.

In order to compare all logistics service factors at the same level of the hierarchical structure, the priority weight and ranking are also complete. The local weight, global weight, and ranking of key factors in each level are summarized in Table 9.

Table 9. The aggregated ordinal numbers of sub-key factors in each of key factors

\begin{tabular}{|c|c|c|c|}
\hline Level 2 Key factor & Level 3 Sub-key factor & $\begin{array}{l}\text { Global } \\
\text { weight }\end{array}$ & Rank \\
\hline \multirow{3}{*}{$\begin{array}{c}\mathrm{C}_{1}: \text { Price of service } \\
(0.333)\end{array}$} & $\mathrm{C}_{11}$ : Transport price $(0.454)$ & 0.151 & 2 \\
\hline & $\mathrm{C}_{12}$ : Packaging price $(0.379)$ & 0.126 & 4 \\
\hline & $\mathrm{C}_{13}:$ Insurance price $(0.167)$ & 0.056 & 6 \\
\hline \multirow{4}{*}{$\begin{array}{c}\mathrm{C}_{2} \text { : History of company } \\
(0.209)\end{array}$} & $\mathrm{C}_{21}$ : Trust and fairness $(0.151)$ & 0.032 & 10 \\
\hline & $\mathrm{C}_{22}$ : Financial stability (0.036) & 0.008 & 16 \\
\hline & $\mathrm{C}_{23}$ : Company experience $(0.189)$ & 0.040 & 8 \\
\hline & $\mathrm{C}_{24}$ : Quality of service $(0.623)$ & 0.130 & 3 \\
\hline \multirow{3}{*}{$\begin{array}{l}\mathrm{C}_{3} \text { : Dissemination of } \\
\text { information }\end{array}$} & $\mathrm{C}_{31}$ : Information system and technology $(0.454)$ & 0.017 & 12 \\
\hline & $\mathrm{C}_{32}$ : Information sharing $(0.167)$ & 0.006 & 17 \\
\hline & $\mathrm{C}_{33}$ : Frequently updating $(0.379)$ & 0.015 & 15 \\
\hline \multirow{2}{*}{$\begin{array}{l}\mathrm{C}_{4} \text { : Relationship with customer } \\
\text { and business partnership }(0.044)\end{array}$} & $\begin{array}{ll}\mathrm{C}_{41} \text { : Customer relationship } \quad(0.625) \\
\end{array}$ & 0.027 & 11 \\
\hline & $\mathrm{C}_{42}:$ Partnership in business $(0.375)$ & 0.016 & 14 \\
\hline \multirow{5}{*}{$\begin{array}{r}\mathrm{C}_{5} \text { : Delivery } \\
(0.376)\end{array}$} & $\mathrm{C}_{51}$ : Short lead time $(0.266)$ & 0.100 & 5 \\
\hline & $\mathrm{C}_{52}$ : On-time delivery $(0.450)$ & 0.169 & 1 \\
\hline & $\mathrm{C}_{53}:$ Prompt response to claim $(0.044)$ & 0.017 & 12 \\
\hline & $\mathrm{C}_{54}:$ Delivery accuracy $(0.105)$ & 0.039 & 9 \\
\hline & $\mathrm{C}_{55}:$ Flexibility in operation $(0.135)$ & 0.051 & 7 \\
\hline
\end{tabular}

As aggregated ordinal numbers of sub-key factors in Table 9, there are the same calculation have been applied to the other pair-wise comparison matrices and the priority weight of each sub-key factors are calculated. The priority weights of each sub-key factors in each of key factors are summarized. According to research finding, the result of suitable approach shows that there are priority weight of sub-key factors in Thailand. Those KSFs depend on the principle of KSF (Daniel. 1961). It is interesting that three to four important ranks which are influenced for selecting C2C logistics company. As the result, we can mention that there are four important ranks of this study that consist of on-time delivery (0.169), Transport price $(0.151)$, Quality of service (0.130) and packaging price (0.126) are appeared. Thus, the meaning and the reason for selecting the KSFs in each order of important factor in Thailand will be explained below.

On-time delivery: On-time delivery is one of important KSFs in transportation term, it relates to customer satisfaction and repurchase intentions. Entrepreneurs have emphasized to on-time delivery because the customers are serious in the delivery time of their product. Therefore, the entrepreneurs in $\mathrm{C} 2 \mathrm{C}$ online market should be selecting the on-time delivery as a one strategies in their business.

Transport pricing: Transport pricing has been one of the most important factors that affect consumer's satisfaction in logistics service provider. The cheap price is always the best choice for Thai C2C online market, cheap transport pricing can help to decrease product's price. Entrepreneurs will have more competitive advantages when they want to negotiation with their customer. Thus, the most strategic of logistics provider should be think about the reasonable price in their service work

Quality of service: Quality of service is an efficiency point of C2C logistics companies that make customers consider logistics service provider. According to quality of service, there are many factors are in this issue that comprise of care, skill, and diligence. Those factors are accordance belong the applicable professional logistics standards which are recognized by most consumers, Thai customers will realize in this term. Most of Thai customers will mention spread widely about the company name, if logistics companies can provide a good quality of service to customer. Thus, $\mathrm{C} 2 \mathrm{C}$ logistics companies should be responsible for the professional quality and coordination of all logistics service under customer's agreement.

Packaging price: Packaging is more than just the wrapping for product. Packaging has been designed for protecting every effect from breakage rates in shipment. Packaging price will depend on two factors that consist of the size and material of package. The Thai customer will consider the selecting of size and material of packaging, because it will directly effect to its price. 


\section{Conclusion}

The complexity of decision making has happened to the buyer and seller in $\mathrm{C} 2 \mathrm{C}$ online market, the problem are; "How to select these $\mathrm{C} 2 \mathrm{C}$ logistics companies" and "Which factors use to select these $\mathrm{C} 2 \mathrm{C}$ logistics providers". Thus this study investigate the important factors that affect to the behavior of consumers for selecting the $\mathrm{C} 2 \mathrm{C}$ logistics companies, determines the important factors which given a better comprehension of the importance trends in decision-making. In this research has investigated the important factor trends of $\mathrm{C} 2 \mathrm{C}$ logistics provider and identify relevant factors from important factor trend by searching in the related literature. Then, we can arrange potentially factors cooperate with decision hierarchical structure. The levels of factors in decision hierarchical structure were determined by questionnaire survey. This research has been applied the Analysis Hierarchy Process (AHP) method cooperated with fuzzy Logic to calculate in the global weight by comparison in each important factor. In this research focus on 4 KSFs that depend on the principle of (Daniel. 1961) are show as following: "Short lead time", "On-time delivery", "Transport pricing" and "Packaging price".

According to the result, the findings of this research has provided a reference for logistics conducting and also make a decision making for considering guideline of online market in Thailand. We conclude with this empirical study that it found out the KSFs can propel buyer and seller (customer to customer) in online market to select $\mathrm{C} 2 \mathrm{C}$ logistics provider. As the result, we can claim that the weight in each important factor seems to be more reasonable in Thailand. Moreover, the analysis result of this research model, we can propose these finding are reason for selecting $\mathrm{C} 2 \mathrm{C}$ logistics companies that can be used to be the one concept in other research as well.

\section{Acknowledgment}

I am really thank DTAIC and National Pingtung University of science and Technology that help me to get more opportunity during studying the doctor of philosophy in Taiwan.

\section{References}

[1] Barua, A., \& Lee, B. (1997) An Economic Analysis of the Introduction of an Electronic Data Interchange System. Information System Research, 8, 1047- 7047.

[2] Boyson, S., Corsi, T., Dresner, M., \& Rabinovich, E. (1999) Managing third party logistics relationships: what does it take. Journal of Business Logistics, 20(1), 73-100.

[3] Burt, S. and Sparks, W. (2003) E-commerce and the retail process: a review, Journal of Retailing and Consumer Services, 10, 275286.

[4] Buyukozkan, G., Feyzioglu, O., and Nebol, E. (2008) Selection of the strategic alliance partner in logistics value chain. International Journal Production Economics, 113,148 -158.

[5] Chang, H.L., and Yeh, C.C. (2005) Factors affecting the safety performance of bus companies-The experience of Taiwan bus deregulation. Safety Science, 43, 323-344.

[6] Daniel, D. R. (1961) Management Information Crisis. In: Harvard Business Review, 39(5), 111-116.

[7] Dolan, J. (2008) Shared decision-making - transferring research into practice: The Analytic Hierarchy Process (AHP). Patient Education and Counseling, 73, 418-425.

[8] Dubiel, M. (1996) Costing structures of reusable packaging systems. Packaging Technology and Science, 9, 237-254

[9] Duclos, L.K., Vokurka, R.J. and Lummus, R.R. (2003) A conceptual model of supply chain flexibility. Industry Management and Data System, 103(6), 446-456.

[10] Gefen et al., (2003) The online consumer trust construct: A Web Merchant Partition Perspective. Proceedings of the 7th Annual Conference of the Southern Association for Information Systems.

[11] Gol, H. and Saaty, B. (2007) Third-party logistics provider selection: insights from a Turkish automotive company. Supply Chain Management: An International Journal, 12 (6), 379-384.

[12] Golob, T.F., Regan, A.C., (2001) Impacts of information technology on personal travel and commercial vehicle operations: research challenges and opportunities. Transportation Research Part C, 9, 87-121.

[13] Gunasekaran, A. et al., (2002) E-commerce and its impact on operations management. International Journal: Production Economics, 75, 185-197.

[14] Hickson, A. (2006) Motor vehicle insurance rating with pseudo emissions coverage. Ecological Economics, 58,146- 159.

[15] Jharkharia, S., and Shankar, R. (2007) Selection of logistics service provider: An analytic network process (ANP) approach. The International Journal of Management Science, 35(3), $274-289$.

[16] Karsak, E. E., and Tolga, E. (2001) Fuzzy multi-criteria decision making procedure for evaluating advance manufacturing system in investment. International Journal of Production Economics, 69, 49-64.

[17] Kahraman, C., Cebeci, U., and Ruan, D. (2004) Multi-attribute comparison of catering service companies using fuzzy AHP. The case of Turkey.International Journal of Production Economics, 87, 171-184.

[18] Kannan, G. (2009) Fuzzy approach for the selection of third party reverse logistics provider. Asia Pacific Journal of Marketing and Logistics. Asia Pacific Journal of Marketing and Logistics, 21(3), 397-416.

[19] Ketikidis, P.H., Koh, S.C.L. Dimitriadis, N., Gunasekaran, Kehajova, A. (2008) The use of information systems for logistics and supply chain management inSouth East Europe: Current status and future direction. The International Journal of Management Science, 36, $592-599$.

[20] Keskinen, A., Delache, X., Cruddas, J., Lindjord, J.E., Iglesias, C., (2002) A Purchase and a Chain. Impacts of E-commerce on Transport and the Environment. OECD, Paris.

[21] Kiku, J., Lori N.K., Leonard (2008) Trust in consumer-to-consumer electronic commerce. Information \& Management, 45, 88-95.

[22] Lee, A.H.I., Chen, W.C., and Chang, C.J. (2008) A fuzzy AHP and BSC approach for evaluating performance of it department in the manufacturing industry in Taiwan. Expert Systems with Application, 34, 96-107.

[23] Liang, G.S., Chou, T.Y., and Kan, S.F. (2006) Applying fuzzy quality function deployment to identify service management requirements for an ocean freight forwarder. Total Quality Management, 17(5), 539-554. 
[24] Lin, C.K.Y. (2008) A cooperative strategy for a vehicle routing problem with pickup and delivery time windows. Computers and Industrial Engineering, 55,766-782.

[25] Liu, H., and Wang, W. (2009) An integrated fuzzy approach for provider evaluation and selection in third-party logistics. Expert Systems with Applications, 36, 4387-4398.

[26] Lu, C. (2003) The impact of carrier service attributes on shipper-carrier partnering relationships: a shipper's perspective. Transportation Research Part E, 39, 399-415.

[27] Menon M., McGinnis M., Ackerman K. (1998) Selection criteria for providers of third-party logistics services: an exploratory study, Journal of Business Logistics, 19, 121-137.

[28] Mokhtarian, P.L., (2002) Telecommunication and travel: the case for complementarity. Journal of Industrial Ecology, 6(2), $43-57$.

[29] Ozgener,S., \& Iraz, R. (2006) Customer relationship management in small-medium enterprises: The case of Turkish tourism industry. Tourism Management, 27, 1356-1363.

[30] Rahman, Z. \& Qureshi, M.N. (2007) Integrating the supply chain flows for business effectiveness. Studies in Business and Economics, 13(1), 5-20.

[31] Saaty, T. L. (1980) The analytic hierarchy process. New York: McGraw Hill.

[32] Sheu, J. B. (2004) A hybrid fuzzy-based approach for identifying global logistics strategies. Transportation Research part E, 40, 3961.

[33] Spencer, M.S., Rogers, D.S. \& Daugherty, P.J. (1994) JIT systems and external logistics suppliers. International Journal of Operations \& Production Management, 14(6), 60-74.

[34] Stank, T. P., Goldsby, T. J., Vickery, S. K., \& Savitskie, K. (2003) Logistics service performance: Estimating its influence on market share. Journal of Business Logistics, 24(1), 27-55.

[35] Tate, K. (1996) The elements of a successful logistic partnership. International Journal of Physical Distribution \& Logistics Management, 26(3), 7-13.

[36] Treville, D., Shapiro, R.D., and Hameri, AP. (2004) From supply chain to demand chain: the role of lead time reduction in improving demand chain performance. Journal of Operations Management, 21, 613-627.

[37] Weltevreden, J.W.J. and Van Rietbergen, T. (2007) E-shopping versus city centre shopping: the role of perceived city centre attractiveness. Journal of Economic \& Social Geography (TESG), 98, 68-85.

[38] Weltevreden, J.W.J., \& Rotem-Mindali, O. (2009) Mobility effects of b2c and c2c e-commerce in the Netherlands: a quantitative assessment. Journal of Transport Geography, 17,83-92.

[39] Williamson, O. E. (1985) The Economic Institutions of Capitalism. New York: Free Press.

[40] Wrigley, N., Lowe, M. and Currah, A. (2002) Retailing and e-tailing. Urban Geography, 23, 180-197.

[41] Wong, J.Y. and Chou, Y- C. (2006) Decision analysis: methods and application. Taipei: Hwa Tai Publishing.

[42] Young, D.E. (2000) Testing and evaluation of transport packaging: a view to the future. Package Technol. Sci, $13,3-6$.

[43] Zadeh, L. A. (1965) Fuzzy sets, Information and Control, 8(3), 338-353. 